\title{
HARTOG, François. Memória de Ulisses: narrativas sobre a fronteira na Grécia antiga. Tradução de Jacyntho Lins Brandão. Belo Horizonte: UFMG, 2004 (479 p.) ISBN: 85-7041-164-2
}

François Hartog, conhecido no Brasil pelas pesquisas na área dos Estudos Clássicos, e por publicações como $O$ Espelho de Heródoto: ensaio sobre a representação do outro (1999) e A História de Homero a Santo Agostinho (2001), traz um brilhante estudo em Memória de Ulisses: narrativas sobre a fronteira na Grécia antiga. Em uma breve introdução, Hartog define os objetivos de seu estudo: as narrativas de viagem como operadores discursivos e esquemas narrativos. Tomando algumas figuras de viajantes, o autor pretende observar a alteridade, o movimento "entre o mesmo e o outro da cultura grega". A importância da questão ver/saber, bastante discutida em $O$ Espelho de Heródoto, percorrerá as analises em todo o livro. Segundo Hartog, trata-se de um estudo de "antropologia e de história da Grécia - ou de uma história cultural de longa duração" (p. 13-14). Esse recorte temporal é bem marcado, pois no passar das páginas vamos de Ulisses ao Abade Barthélemy. Assim como seus guias, viajantes reais ou fictícios, o historiador francês também tem um percurso a fazer pelo mundo antigo.

A viagem começa com "O retorno de Ulisses", viajante a contragosto, onde se estabelecem as principais categorias da antropologia grega. Viagem canônica e fundadora, na Odisseia são pensadas as categorias que fazem o homem enquanto tal, a visão que os gregos tiveram de si mesmos e a partilha fundamental entre humano/imortal/inumano. Na perspectiva da longa duração, Hartog analisa a figura de Ulisses em outros tempos e espaços, desde Heródoto que invoca a experiência da viagem, à Renascença, época de viagens e descobertas.

Num movimento inverso, Hartog embarca nas "Viagens do Egito", partindo da Expedição do Egito (1798), comandada pelo general Bonaparte. O tema do Egito como civilizador da Grécia é discutido, observando seu sentido dentro da cultura grega. $\mathrm{O}$ historiador conclui que não há um olhar único no imaginário grego com relação ao Egito, mas uma sucessão de olhares, num emaranhamento de opiniões políticas, intelectuais e religiosas. Há, porém, um traço comum que é o da antiguidade da região. Do Egito de Menelau, passando pelos mercenários gregos, Platão e o "panegiptismo" de Hecateu de Abdera, Hartog segue a temática do religioso e sua alteração nos diferentes momentos.

Da visão entre o eu-grego e o outro, partimos para a análise da "Invenção do Bárbaro e inventário do mundo". Para Hartog, trata-se de dois momentos mais ou menos concomitantes: a invenção do bárbaro e um inventário do mundo, isto é, um 
desenvolvimento da ciência grega (principalmente jônica), num movimento de recolher conhecimentos, organizá-los e representar o mundo. As Guerras Médicas tiveram papel catalizador na formação do bárbaro (bárbaroi) em oposição ao grego (héllenes), além de territorializar o bárbaro na figura dos persas. Com as Histórias, de Heródoto, a partilha entre gregos e bárbaros se torna política e bárbaro não significa especificamente a barbárie, mas o não conhecimento da pólis e a submissão a reis. Nesse ponto, Hartog reflete sobre o tratamento do espaço, da representação física do mundo e de suas culturas (tal como no sistema operado por Heródoto) para discutir a questão do centro e dos confins, da disposição espacial das culturas e, por fim, da natureza dos povos. A figura do bárbaro como problema político passa a ser substituída pela questão cultural, ao passo que a "grecidade" se torna uma questão de educação. O questionamento das partilhas e de uma identidade grega canônica é realizado pelos cínicos, com a desvalorização do centro, da sophía, em proveito da simplicidade e da pureza dos confins.

No capítulo "Viagens da Grécia", Hartog propõe observar os olhares gregos sobre si mesmos, tomando como guias principais Anácarsis, Pausânias, Plutarco e Alexandre. Trata-se de observar as fronteiras, que passam de marcos reais à constituição do imaginário e da identidade grega. Continuando a discussão do capítulo anterior sobre "grecidade" e educação, Hartog problematiza novamente a partilha fundamental (homem/deus/animal), desdobrando a discussão do paralelo animal/homem na vida dispersa ou em comunidade, no par campo/cidade, que retoma também a questão centro/confins.

Nas "Viagens de Roma", Hartog nos mostra a inserção dos romanos na grande partilha entre gregos e bárbaros. Para tanto, são utilizadas as viagens de Dionísio de Halicarnasso, para o qual os romanos são autênticos gregos "desde o primeiro dia", e Políbio, que explicou o domínio de Roma pela superioridade de seu regime político e que Cícero chama de "nosso Políbio"; também as viagens de Estrabão, que via o mundo a partir de Roma, e Élio Aristides, cuja Roma era uma "cidade remendada de estrangeiros; todo mundo está nela como em casa”, ou seja, “o mundo está em Roma e o romano é como um cidadão do mundo" (p. 219).

A viagem tem um fim com Apolônio, o exportador de sabedoria, o embaixador de um pan-helenismo renovado, um reflexo de Pitágoras, seu mestre, "uma das figuras através das quais a cultura grega manifestou o lugar que atribuía ao outro (...) um 


\section{nuntius antiquus}

dispositivo em que se combinam abertura e controle, inquietude e segurança, reconhecimento e desconhecimento, tradução e traição, que, para começar, apoia-se no filtro e na garantia do falar grego" (p. 233). A viagem de Hartog, tal qual a viagem de Ulisses, não cansa o leitor, pelo contrário, lhe dá fôlego renovado.

Vivian da Cunha Mendes Caldeira

FALE-UFMG 